\title{
Principles of Fairness for International Economic Treaties: Constructivism and Contractualism
}

John Linarelli

Touro Law Center, jlinarelli@tourolaw.edu

Follow this and additional works at: https://digitalcommons.tourolaw.edu/scholarlyworks

Part of the Economic Policy Commons, International Law Commons, Law and Economics Commons, Law and Philosophy Commons, Legal Theory Commons, and the Transnational Law Commons

\section{Recommended Citation}

John Linarelli, Principles of Fairness for International Economic Treaties: Constructivism and Contractualism (June 21, 2005), in TRADE AS THE GUARANTOR OF PEACE, LIBERTY AND SECURITY PERSPECTIVES 124 (Padideh Ala'i, Tomer Broude, \& Colin Picker, eds., 2006).

This Book Chapter is brought to you for free and open access by the Faculty Scholarship at Digital Commons @ Touro Law Center. It has been accepted for inclusion in Scholarly Works by an authorized administrator of Digital Commons@ @ouro Law Center. For more information, please contact Iross@tourolaw.edu. 


\title{
PRINCIPLES OF FAIRNESS FOR INTERNATIONAL ECONOMIC TREATIES: CONSTRUCTIVISM AND CONTRACTUALISM
}

\author{
John Linarelli \\ Rules are "mere labels for more complex ideas."
}

\section{Introduction}

Longstanding discontent persists about the role of international economic institutions in the global economy. Some perceive globalization as producing substantial injustice. ${ }^{2}$ Those who find globalization to be good blithely dismiss the objections of those who do not. Writing on the protests that occurred at the World Trade Organization (WTO) Seattle Ministerial Conference, Thomas Friedman wrote in the New York Times, "Is there anything more ridiculous in the news today that the protests against the World Trade Organization in Seattle?" Friedman called the protestors "a Noah's ark of flat-earth advocates, protectionist trade unions and yuppies looking for their 1960s fix." ${ }^{3}$ It seems like neither side knows that the other is talking about - a cognitive or linguistic inability to understand each other.

Much of the criticism of the WTO and the other multinational economic institutions focuses on the power of multinational enterprises. What power do multinationals actually exert on the policies and operations of these institutions? The influence of the multinational enterprises has been difficult

? Professor of Law, University of La Verne College of Law, Ontario California, john linarelli@ulv.edu. I am grateful to Carl Cranor for valuable comments. All errors are mine.

${ }^{1}$ T.M. Scanlon, What We Owe to Each Other (Harvard University Press 1998): 199.

${ }^{2}$ For example, the French sociologist Pierre Bourdieu says that globalization: is a myth in the strong sense of the word, a powerful discourse, an idea force, an idea which has social force, which obtains belief . . . It ratifies and glorifies the reign of what are called financial markets, in other words, the return of a kind of radical capitalism, with no other law than that of maximum profit, an unfettered capitalism without any disguise, but rationalized, pushed to the limit of its economic efficacy by the introduction of modern forms of domination, such as "business administration," and techniques of manipulation such as market research and advertising. ... In short, globalization is not homogenization; on the contrary, it is the extension of the hold of a small number of dominant nations over the whole set of national financial markets.

Pierre Bourdieu, Acts of Resistance: Against the Tyranny of the Market (New Press 1999).

${ }^{3}$ This is from Thomas Friedman's December 1, 1999 column in the New York Times, quoted in Peter Singer, One World: The Ethics of Globalization (Yale University Press $2^{\text {nd }}$ ed. 2004): 52. 
to articulate and explain in terms familiar to lawyers and policy makers. We have trouble breaking out of the barriers we are educated to respect. Public choice theory informs us that we should be concerned about the influence of powerful lobbying groups who work within the political processes of the governments of the WTO members themselves. These interest groups, the story goes, capture the negotiating positions of powerful WTO members and influence the agenda, as it is set in the WTO negotiating rounds and in the work done between the rounds. They exercise a similar sway over the policies and operations of other international economic institutions such as the International Monetary Fund and the development banks. For example, if we want to understand the Agreement on Trade Related Aspects of Intellectual Property Rights (TRIPs), we might want to inquire about the role of the pharmaceutical industry, of the film and recording industries, in assisting the United States Government in formulating negotiating positions for TRIPs. The argument is that these interest groups persuade the governments of highincome countries that TRIPs should contain a strong set of intellectual property protections that go far beyond the traditional remit of what the GATT/WTO framework ever aspired to previously. ${ }^{4}$ Because of such influence, the argument goes, the multinationals are able to get what they want, and what they want results in unfair agreements. The WTO agreements, the argument continues, comply with few or no standards of fairness, or if they do, it is accidental. They may lower tariffs and barriers to trade in services so that companies can effectively operate across borders, but they may also maintain barriers to trade to protect powerful interests who benefit from protectionism. These are the arguments. I summarize them; I do not necessarily accept them, at least in their simple form.

Does the divisiveness derive from a lack of a consensus on a theory of justice with which we can deliberate about the merits of international economic agreements? No legal system deserving of continued support can exist without an adequate theory of justice. This paper is about the elaboration of a theory of justice to underpin international economic law and international economic institutions. A world trade constitution cannot credibly exist without a clear notion of justice upon which to base a consensus. Despite attempts to describe a world trade "legal system" or constitution, no such system or constitution yet exists in a way credible to many people. There is yet no consensus on the public reason underpinning the rules and the institutions. Much of the antiglobalization dissent, though sometimes unfocused and confused, seems bottomed on the basic notion that a legal system requires a theory of justice. Governments will never get their populaces to embrace international economic

${ }^{4}$ See, e.g., Pamuela Samuelson, "Intellectual Property and the Digital Economy: Why the Anti-Circumvention Regulations Need to be Revised," Berkeley Technology Law Journal, 1999, 14: 519. 
law and institutions without a consensus on what is just in the international economic sphere. Scholars and practitioners have expended great effort in improving our understanding of world trade rules and policies, but the normative dimensions of such inquiry seems incomplete without an underlying consensus of sufficiently wide scope on the reasons for the rules and policies. That the rules and policies now encroach upon areas of domestic regulation in sensitive policy areas serves to highlight the problem.

Economic efficiency has been the benchmark often used to evaluate the merits of international economic agreements. Economic efficiency is a commonly understood aspiration embedded in the idea of progressive liberalization; the progressiveness of liberalization is determined based on efficiency gains. I have no qualms about economic efficiency. I think it is a valuable tool and I think economists bring a very useful toolkit to the table. I am not going to expend any effort in bashing economics because such bashing is wrongheaded. I refocus away from economics, however, away from the efficiency versus distribution dimensions of conceptualizing the effects of international economic institutions. I devote this paper to examining approaches to understanding the allocation of resources that most economists are unwilling to devote much energy analyzing. I have nothing against economics, but I do not see how we can base a constitutional system solely on it. None in fact is. Politicians really are not that interested in efficiency. Why should efficiency be the default rule? Not everyone accepts it.

One of the questions I explore is Kantian in influence: is there a constructivist procedure that is both universal and cosmopolitan, that we can apply to understand international economic agreements better - to improve our deliberation about the WTO and to develop a consensus on what is and is not acceptable? This paper is located firmly in moral philosophy and hangs closely to deontological approaches to moral philosophy. No "critical" or postmodern approaches are undertaken. Banned are trendy left theories from these pages. ${ }^{5}$

The paper examines alternatives to the question of what should be a proper distributional framework for the design of international economic treaties and institutions. There are many standards, intended primarily for application to nation-states but extended here to global society. In this paper, I discuss two approaches, those of John Rawls and T.M. Scanlon, with the focus primarily on Scanlon's work. The natural starting point for any discussion of moral theory in the context of social institutions is Rawls's A Theory of Justice. ${ }^{6}$ I will not spend a great deal of time on Rawls, though he offers the most

\footnotetext{
5 As an example, I have in mind here Michael Hardt \& Antonio Negri, Empire (Harvard University Press 2001).

${ }^{6}$ John Rawls, A Theory of Justice (Harvard University Press rev. ed. 1999).
} 
influential account. ${ }^{7}$ I cannot avoid Rawls. Rawls wrote the most influential piece of moral philosophy in the twentieth century. His A Theory of Justice must form a base to discuss a cousin theory that has gained a good deal of recent popularity, the contractualist account of T.M. Scanlon, the most recent elaboration of which is in Scanlon's What We Owe to Each Other. ${ }^{8}$

We could focus on other theories. I would have to write a book rather than a paper if I were to exhaustively survey theories in competition with Rawls's theory of justice, but it is worth at least brief mention of a few. Amartya Sen and Martha Nussbaum propose that governments should maximize people's basic capabilities. ${ }^{9}$ To Sen and Nussbaum, some goods are inputs needed to function in society. They propose that governments equalize the ability to function in a society. The capabilities approach has had some influence on the United Nations Development Programme (UNDP), which in 1993 began to assess quality of life using the concept of people's capabilities. ${ }^{10}$ Ronald Dworkin argues that there should be equality of basic resources available to persons, with a mechanism for valuing nontransferable resources (such as native talent) in terms of transferable resources. ${ }^{11}$ Gerard Cohen argues for equalizing access to advantage. ${ }^{12}$ I could go on with this list. Let me mention just one more because her theory will get lots of play in the coming years. Susan Hurley articulates a cognitivist theory of distributive justice, which aims to neutralize bias, to develop greater public agreement on what is good. ${ }^{13}$ Hurley's idea of cognitive theory focuses on the meta-ethics of justice concepts. She wants to solve the problem of the divide between private and public reason that Rawls deals with in Political Liberalism. ${ }^{14}$

\footnotetext{
${ }^{7}$ Frank Garcia has done a series of important articles on Rawls and world trade. See, e.g., Frank J. Garcia, "Beyond Special and Differential Treatment," Boston College International and Comparative Law Review, 2004, 27: 291; Frank J. Garcia, "Building a Just Trade Order for A New Millennium," 33 George Washington International Law Review, 2001, 33: 1015; Frank J. Garcia, "Trade and Inequality: Economic Justice and the Developing World," Michigan Journal of International Law, 2000, 21: 975.

${ }^{8}$ Scanlon, n. 1.

9 Amartya Sen, On Economic Inequality (Oxford University Press 1973); Amartya Sen, "Equality of What?" in The Tanner Lectures on Human Values, S. McMurrin ed., (University of Utah Press 1980): 197-220; Amartya Sen, Inequality Reexamined, (Harvard University Press 1992); Martha Nussbaum, "Capabilities and Human Rights," in Global Justice and Transnational Politics, Pable De Greiff \& Ciaran Cronin, eds., (The MIT Press 2002): 117-49.

${ }^{10}$ Nussbaum, 119.

${ }^{11}$ Ronald Dworkin, "What is Equality? Part 1: Equality of Welfare," Philosophy and Public Affairs, 1981, 10: 283-45; Ronald Dworkin," What is Equality? Part 2: Equality of Resources," Philosophy and Public Affairs, 1981, 10, 283-345.

${ }^{12}$ Gerard A. Cohen, "On the Currency of Egalitarian Justice," Ethics, 1989, 99, 4: 906-44.

${ }^{13}$ Susan L. Hurley, Justice, Luck and Knowledge (Harvard University Press 2003).

${ }^{14}$ John Rawls, Political Liberalism (Columbia University Press 1995).
} 
I do not discuss rules in a comprehensive way, though I do "apply" the tools set forth in this paper to one persistent problem - the regulation of intellectual property rights at the WTO level and access to pharmaceuticals in low-income countries. Rules are very important. Nevertheless, I do not think this project is at the stage yet where I can offer systematic applications of the decision procedures set forth in this paper. At most, one could say that this paper is about what lawyers call policies about rules. The focus is on how to evaluate whether a rule is desirable or not based on an underlying value. This paper is representative of a project, one to articulate philosophical thought about justice for application in the future, perhaps to compare with efficiency results. Looking at theories of justice seems required if governments are to come up with meaningful cross-cultural comparisons of quality of life. What are the norms for evaluating the so-called constitutional order? We cannot claim to have a constitutional order without understanding what that order is based upon. It is difficult to have a conversation about global injustice without common standards.

So many ways of approaching this project exist that undoubtedly I am open to criticism for failing to address something. I have been very selective in this paper. Some may see as a glaring omission that I am not expending much effort discussing human rights. Others have said much more about human rights that I can say. For discussions from the perspective of philosophy see publications by Pogge ${ }^{15}$ and Habermas, ${ }^{16}$ and from the perspective of a philosophically informed legal scholar see publications by Petersmann. ${ }^{17}$ If this is a weakness in my approach, it is one shared with others. Onora O'Neill, for example, a prominent Kantian, in her important work on justice explains that "[t]he most significant structures of ethical concern can be expressed in linked webs of requirements, which are better articulated by beginning from the perspective of agents and their obligations rather than that of claimants and their rights." 18 The idea here is that "there can be

15 See, e.g., Thomas Pogge, "Human Rights and Human Responsibilities," in De Greiff \& Cronin, 151-95.

16 See, e.g., Jürgen Habermas, On Legitimation Through Human Rights, in De Greiff \& Cronin, 197-214.

${ }^{17}$ See, e.g., Ernst Ulrich Petersmann, "The WTO Constitution and Human Rights," Journal of International Economic Law 3 (2000): 19-25; Ernst Ulrich Petersmann, "Human Rights and International Economic Law in the Twenty-First Century: The Need to Clarify Their Relationship," Journal of International Economic Law 4 (2001): 3-39; Ernst Ulrich Petersmann, "From Negative to Positive Integration in the WTO: Time for "Mainstreaming Human Rights' into WTO Law?,” Common Market Law Review 37 (2000): 1363-82.

${ }^{18}$ Onora O'Neill, Towards Justice and Virtue: A Constructive Account of Practical Reasoning (Cambridge University Press 1996): 4. 
requirements on us that no one has any standing to require of us." ${ }^{, 19}$ Whether we want to "legalize" these requirements to produce legally binding obligations, so that someone has such standing in the courts, is a question for policy makers informed by the standards found in this and in other works.

\section{Rule Orientation and Implications for Fairness}

One of the most significant achievements of the Uruguay Round was the negotiation of the Dispute Settlement Understanding (DSU). The DSU creates the rules and the institutions for binding settlement of disputes relating to WTO agreements between or among WTO members. The DSU by its own terms, explains that " $[\mathrm{t}]$ he dispute settlement system of the WTO is a central element in providing security and predictability to the multilateral trading system." 20 The DSU is an important stage in the evolution of the world trading system towards legalism, in which "legalist" approaches to dispute settlement in the world trading system evolve from "pragmatist" approaches, based primarily in diplomacy. ${ }^{21}$ Some contend that there is a move towards legalization in the international sphere generally, and that the WTO is one good example of this trend. ${ }^{22}$

Jackson's rule-versus-power orientation is one of the most important and well-known insights in the literature on world trade law. ${ }^{23}$ In making this distinction Jackson, a careful scholar, made few claims about the justice of the rules. He does not say that the WTO agreements and institutions constitute a legal system. But he opened the way for thinking about whether the WTO is actually a legal system. Some scholars claim that the WTO system is constitutional, that a "world trade constitution" exists. ${ }^{24}$ Others, relying on positivist notions of the law found in Hart and even in Austin, make claims about the existence of a world trade legal system. ${ }^{25}$

\footnotetext{
${ }^{19}$ Stephen Darwall, "Respect and the Second Person Standpoint," Proceedings and Addresses of the American Philosophical Association 78: 2, 43-59, 44.

${ }^{20}$ Dispute Settlement Understanding Art. 3.2.

21 See G. Richard Schell, "Trade Legalism and International Relations Theory: An Analysis of the World Trade Organization, Duke Law Journal, 1995, 44: 829.

22 Ibid.; Judith Goldstein, Miles Kahler, Robert Keohane \& Anne-Marie Slaughter eds., Legalization and World Politics (MIT Press 2001).

23 John H. Jackson, The World Trading System: Law and Policy of International Economic Relations (The MIT Press $2^{\text {nd }}$ ed. 1997).

24 John O. McGinnis \& Mark L. Movsesian, "The World Trade Constitution," Harvard Law Review, 2000, 114: 511. Add more cites.

25 Raj Bhala \& Lucienne Attard, "Austin's Ghost and DSU Reform," International Lawyer, 2003, 32: 651; David Palmeter, "The WTO as a Legal System," Fordham International Law Journal, 2000, 24: 444.
} 
Two kinds of theories about the international legal order are influential in the present day: positivist and instrumental. Both these theories maintain longstanding relationships going back to Bentham, who was both a positivist and a utilitarian. Both approaches fail to provide adequate accounts of justice. Positivism is obsessed with the pedigree of rules. In its exclusive form, it requires the separation of law and morality and in its inclusive form; it denies any necessary connection between law and morality but admits that a connection between law and morality is possible. Clearly, positivism does not require any moral criteria to assess the pedigree of legal rules. Instrumentalists, most notably law and economics scholars, argue that concepts of justice are rhetorical. Eric Posner and Jack Goldsmith, for example, argue that states use "moralistic and legalistic rhetoric" to advance their own interests. ${ }^{26}$ Why this rhetoric (if it is rhetoric) is less helpful in furthering our understanding than the metaphors of game theory, such as "cheap talk" and "signaling" is for another paper, but what the law and economics approach fails to identify is their longstanding connection to a discredited Benthamism. Law and economics scholars make the same arguments about justice that Bentham did in the eighteenth century. In The Principles of Morals and Legislation," Bentham explains in a footnote that "justice, in the only sense in which it has a meaning, is an imaginary personage, feigned for the convenience of discourse, whose dictates are the dictates of utility, applied to certain particular cases. Justice, then, is nothing more than an imaginary instrument, employed to forward on certain occasions, and by certain means, the purposes of benevolence. ${ }^{27}$ In The Theory of Legislation, Bentham says that he uses the words "just" and "unjust" along with other words "simply as collective terms including the ideas of certain pains or pleasures. ${ }^{128}$

One of the major defects that positivism and instrumentalism share is that if we assume that they provide adequate accounts for legal principles, either in pedigree or in rational choice, then they produce bad counterexamples. It is easy to come up with a system of positivistic and efficient rules that are unjust. Justice simply is not a criterion in these accounts.

\footnotetext{
${ }^{26}$ Jack L. Goldsmith \& Eric A. Posner, "Moral and Legal Rhetoric in International Relations: A Rational Choice Perspective," http://papers.ssrn.com/paper.taf?abstract id=250042; see also Jack L. Goldsmith \& Eric A. Posner, The Limits of International Law (Oxford University Press 2005).

${ }^{27}$ Jeremy Bentham, An Introduction to the Principles of Morals and Legislation, J.H. Burns, H.L.A. Hart \& F. Rosen eds. (Oxford University Press rev. ed 1970 ed. 1996) ch. x, footnote 2 to section XL.

${ }^{28}$ Jeremy Bentham, The Theory of Legislation C. K. Ogden ed. (London, 1931):. 3. These references are discussed in John Rawls, "Justice as Fairness," a 1958 paper appearing in the Philosophical Review, and now reprinted in John Rawls, Collected Papers, Samuel Freeman ed. (Harvard University Press 1999): 48-49.
} 
These two prevailing accounts of international economic law, then, positivism and instrumentalism, when combined with concepts from both the normative welfare economics of international trade and from the political economy of international trade, produce a quasi-utilitarian framework for the assessment of international economic law and institutions. ${ }^{29}$ Quasiutilitarianism is, it seems, is the default principle. I use the term quasiutilitarianism because economics is distinct from utilitarianism, particularly from the Millian version of utilitarianism, and because I do not think there is an explicit recognition of utilitarianism as the actual reasons for action in the making of international economic law and policy.

Quasi-utilitarianism has so many problems that I do not know where to begin. Distinguishing other ethical theories from utilitarianism and the broader notion of consequentialism has been one of the major debating tournaments of modern moral philosophy and others far more capable than I have dealt with the issues in depth. I mention just a few weaknesses of utilitarianism here, relevant to international economic law and policy. How does quasiutilitarianism work? The problems are in average utility, the greatest good for the greatest number, and in concepts like Pareto efficiency. These measures fail to account for effects on the worst off. They focus wholly on states of affairs and not on principles. Quasi-utilitarianism tends to engage in an improper aggregation of the effect of a policy into a single judgment, giving inadequate attention to the distributive effects of the policy. Aggregation tends to disguise the adverse effects of a policy on groups who suffer substantial burdens or who may be worse off in the society in question. ${ }^{30}$ Quasiutilitarianism does not deal with the basic problems of desert and luck - that the well-being of people depends on the natural lottery and on social and historic circumstances. Joseph Raz has provided the example of how an act utilitarian must commit to the claim that an extra lick of ice cream for a sufficiently large number of people can justify the killing of another person, if the trivial satisfactions of the many that get the extra licks outweigh the loss suffered by the person killed. ${ }^{31}$ Utilitarian and quasi-utilitarian concepts do not link to concepts humans seem to possess of right and wrong. It is telling that we do not teach our children to be utilitarian, but rather, we try to instill in them the reason-giving force of right and wrong.

\footnotetext{
${ }^{29}$ I borrow the "quasi-utilitarianism phrase from Carl Cranor, "The Genomic Revolution and Intra-National and Inter-National Equity (unpub., on file with the author).

${ }^{30}$ Ibid.

31 Joseph Raz, The Morality of Freedom (Oxford University Press 1988).
} 


\section{Fairness Theories}

My project is to set forth some alternatives to the current default rule of quasi-utilitarianism, so that we may better understand the fairness of international economic law and institutions. As explained above, the natural starting point for any such discussion is Rawls's A Theory of Justice. I will not spend a great deal of time on Rawls, because others have covered Rawls so well, and I want to move on to the more recent work of Scanlon. Before I take on the substantive accounts, some groundwork is necessary.

At the outset, we must be cautious in extending contractualism to provide an account of public morality. Scanlon explains that contractualism applies only to individual conduct. ${ }^{32}$ It is intended for application to the basic question that moral philosophers try to answer, and that is "how should one live." The focus of inquiry in contractualism is thus plainly distinguishable from that of Rawls' A Theory of Justice, which has as its explicit target an account of a public morality. Rawls elaborates in Justice as Fairness: A Restatement, that his principles concern "the basic structure of society, that is, its main political and social institutions and how they fit together into one unified system of social cooperation."33 Considerable problems may appear in trying to extend contractualism from the private to the public sphere, but considerable promise exists in such an extension nonetheless. We will have to work out these problems or contractualism ultimately will not make the move into the political and legal realms.

The theories that I discuss all deal in concepts about principles. They do not focus solely on states of affairs, as economics, utilitarianism and other forms of consequentialism do. Both Rawls and Scanlon blend the two values. They permit a focus on states of affairs, but states of affairs cannot trump principles of fairness. Neither theorist is neutral about principles. Scanlon starts his hugely influential work on contractualism with an account that places his theory within descriptivism, but with little in the way of the metaphysical baggage often associated with such discussion. ${ }^{34}$

Rawls's work is constructivist. Rawls did not use that term in A Theory of Justice. In A Theory of Justice, he does discuss the idea of construction, that his principles of justice provide "constructive criteria" for guiding action. ${ }^{35}$ Rawls distinguishes constructivist from intuitionist approaches. He argues that intuitionism produces a set of impractical and unranked moral principles and

\footnotetext{
32 Scanlon, 228.

33 John Rawls, Justice as Fairness: A Restatement, Erin Kelly ed. (Harvard University Press 2001): 39-40.

${ }^{34}$ Scanlon, 2

35 Onora O’Neill, “Constructivism versus Contractualism, Ratio 2003, 16: 319-31.
} 
thus does not help to guide action. ${ }^{36}$ Thus, the major distinction is between constructivism and realism. ${ }^{37}$ In a constructivist moral theory, moral principles are not "furniture of the universe.,"38 They are not facts independent of and prior to moral reasoning. They however, have validity and are correct when they are the product of a procedure in which a human agent engages in practical reason to articulate and live by a moral principle. In his Lectures on the History of Modern Moral Philosophy, Rawls explains that Kant is a constructivist. "An essential feature of Kant's moral constructivism is that the particular categorical imperatives that give the content of the duties of justice and virtue are viewed as specified by a procedure of construction (the CI procedure). . .."39 Constructivists do not have to be Kantian. Utilitarians are constructivists, as is the neo-Hobbsian David Gauthier. ${ }^{40}$ Rawls is a Kantian constructivist. In his 1980 Dewey Lecture, entitled "Kantian Constuctivism in Moral Theory," Rawls "set out more clearly the Kantian roots of A Theory of Justice" and to elaborate more clearly the Kantian form of constructivism. ${ }^{41}$

Rawls is also a contractualist. In A Theory of Justice, Rawls places his work within the social contract tradition of Kant, Locke and Rousseau. ${ }^{42}$ Scanlon places his work in the tradition of Rousseau. ${ }^{43}$ O'Neill argues that we can read Scanlon to be a constructivist. ${ }^{44}$ To avoid confusion, I use the contractualist label to refer to Scanlon and the constructivist label to refer to Rawls.

\section{A. Rawls: Kantian Constructivism}

A threshold question is whether we can apply Rawlsian justice as fair ness outside of the confines of domestic society. Rawls himself refused to extend his theory to international contexts, but many Rawlsians have argued that the conditions now hold for application of Rawlsian theory at the international

\footnotetext{
${ }^{36}$ O'Neill, "Constructivism versus Contractualism." Rawls makes the same distinctions about Kant. Lectures on the History of Modern Moral Philosophy, Barbara Herman ed. (Harvard University Press 2000): 237-38.

${ }^{37}$ I use the word "realism" in its philosophical sense and not as used in legal thought to refer to legal realism. The two theories are radically different.

${ }^{38}$ See John L. Mackie, Ethics, Inventing Right and Wrong (Penguin reprint ed. 1991).

${ }^{39}$ Rawls, Lectures, 237.

40 O'Neill, "Constructivism Versus Contractualism, 320, David Gauthier, Morals by Agreement (Oxford University Press reprint ed. 1987).

${ }^{41}$ Rawls, Lectures, xiii.

${ }^{42}$ Rawls, Theory of Justice, section 3; xv iii.

${ }^{43}$ Scanlon, 5.

${ }^{44}$ O’Neill, "Constructivism Versus Contractualism."
} 
level. I will not restate those arguments here. ${ }^{45}$ The extension is justified because of the lack of economic self-sufficiency and distributional autonomy between states. $^{46}$ The WTO and other international economic institutions no doubt had a hand in bringing these two conditions into existence.

The Rawlsian theory of justice as fairness is about social justice or public morality. In A Theory of Justice, Rawls explains that the "primary subject" of his principles is "the basic structure of society, the arrangement of social institutions into one scheme of cooperation." 47 Rawls elaborates in Justice as Fairness: A Restatement, that his principles concern "the basic structure of society, that is, its main political and social institutions and how they fit together into one unified system of social cooperation." 48 These principles, Rawls continues, "are to govern the assignment of rights and duties in these institutions and they are to determine the appropriate distribution of the benefits and burdens of social life." principles which apply to individuals and their actions in particular circumstances." 50

The basic structure of the Rawlsian conception of justice is that if mutually self-interested and rational persons stand in relation to each other behind a veil of ignorance in the original position, and if they must choose a conception of the right to order their claims on society in the circumstances of justice, they will agree on two lexically ordered principles of justice. The first principle of justice is that society guarantees each person an equal right to the most extensive scheme of equal basic liberties compatible with a similar scheme of liberties for others. The second principle of justice is that society should arrange social and economic inequalities so that two criteria are met: (1) positions and offices should be open to everyone equally; and (2) social and economic inequalities should benefit everyone regardless of social group. ${ }^{51}$

The focus in discussions of global economic questions has mainly been on the second principle, which has clear implications for assessing the distributive justice of international economic law and institutions. I like others place less emphasis on the first principle, so we do not have to get into the question of public reason on mainly non-economic civil society issues to any great depth. The first principle, dealing with basic liberties and freedoms, goes to the heart of sovereignty. It is the subject of domestic constitutional orders, but also of

\footnotetext{
${ }^{45}$ See Garcia; Allen Buchanan, Justice, Legitimacy and Self-Determination: Moral Foundation of International Law (Oxford University Press 2004); Pogges.

${ }^{46}$ Garcia; Buchanan, 200-27.

${ }^{47}$ Rawls, A Theory of Justice, 47.

${ }^{48}$ Rawls, Justice as Fairness, 39-40.

${ }^{49}$ Rawls, A Theory of Justice 3.

${ }^{50}$ Ibid.

${ }^{51}$ Ibid., 60. I am grateful to Carl Cranor for input on the basic structure of the argument. Carl Cranor, "Rawlsian Choice of Distributive Principles" (unpub., on file with the author).
} 
international human rights and international criminal law regimes. As these international regimes proliferate, some of the responsibilities for securing the first principle move to the international level. That is not my concern here. That the first trumps the second is important for understanding why we should not lightly allow international legal orders to override fair domestic legal orders. The first principle retains its lexical priority institutionally to the extent that governments refuse to agree to treaties that derogate from basic rights and freedoms provided domestically. Difficulties may arise, however, if international tribunals, such as the WTO Dispute Settlement Body, issue decisions that trump basic rights granted domestically. This is an issue for another paper.

Let us look a bit more closely at the second principle. Rawls contends that if we place persons behind a veil of ignorance in the original position, they would choose the difference and fair equality of opportunity principles as principles of equality. At the risk of oversimplifying, the reason for the selection of these principles in the original position is because Rawls does not want to base the distribution of primary social goods (rights, liberties, opportunities, income and wealth) or primary natural goods (health, intelligence and imagination) on initial endowments obtained through luck. When they are behind the veil of ignorance in the original position, people do not know their endowments of these goods.

The second principle permits inequality, and persons can use their unequal endowments to their own benefit, as long as institutions provide incentives to benefit everyone, and in particular the worst off. Let us unpack this second principle. It itself contains two principles, the fair equality of opportunity principle and the difference principle.

The fair equality of opportunity principle holds that positions and offices that result in social and economic inequalities must be open to all. It does not assume or ensure that everyone is equal in talents, abilities and motivation. But, for individuals who are equal in talents, abilities and motivations, they should have an equal chance of attaining the same positions in a given society. Under the fair equality of opportunity principle, social and, in our context here, national starting points are irrelevant because they are arbitrary.

The difference principle essentially provides that inequality must benefit everyone. As long as the primary social goods of the worst off group are increasing, inequality is fair and can continue to increase. As soon as the primary social goods of the worst off group stop increasing, then the society in question has reached the maximum inequality permitted. We can add other groups into this picture. Suppose the welfare of the worst off group plateaus but society could continue to make the best off group (or any better off group) better off with no detriment to the worst off group. Is such a move fair? Inequality can continue, but we have to examine the effects on other groups. Consider the second worst off group. If during increasing inequality, the lot of 
the second worst off group is increasing, so long as society does not make the worst off group even worse off, inequality can continue to increase. The point at which increasing inequality must stop is at the point at which society could make no more moves without making the worst off group or the second worse off group even more badly off. We can generalize the account to $\mathrm{n}$ groups. The emerging concept is the difference principle: A scheme of cooperation is fair if, in the given historical and social circumstances, society can make no further move that would make all (every one) of the representative groups better off. ${ }^{52}$ In other words, pick a regime of norms that makes everyone better off than they would be under any other regime of norms.

Rawls's theory of justice combines two prevailing approaches to moral theory. It is principled. It has a procedure of construction for determining the content of fairness. The veil of ignorance and original position is a universalizing procedure, as is Kant's categorical imperative procedure. Rawls uses principles to evaluate states of affairs. His theory is a hybrid. Rawls does not rely solely on the analysis of states of affairs, as utilitarianism does, but states of affairs surely are important in assessing the lot of groups in society, particularly the worst off. As we shall see in the following part, Scanlon's contractualism shares this hybrid feature.

The relevance of Rawls's theory of justice to the normativity of international economic law and institutions is remarkable. It is no wondering that so many have extended Rawls to the international realm.

\section{B. Scanlon: Contractualism}

In 1982, T. M. Scanlon published an influential paper entitled "Contractualism and Utilitarianism," in which he first proposed his contractualist account of morality. ${ }^{53}$ He since wrote a book on contractualism, What We Owe to Each Other, which revised some of his views, partly in response to critics. ${ }^{54}$ Contractualism has gotten quite a bit of attention in moral philosophical circles, and it is worth investigating its application to institutions. I will not present anything like a complete account of contractualism here. I want to get to the structure of the contractualist argument, to understand its application. The meta-ethical, epistemological and metaphysical questions are for discussion in other venues. Despite the lack of a link to the political realm, I think the best use of contractualism is as a heuristic for evaluating global economic treaties. Contractualism is an ethical framework that has the

\footnotetext{
${ }^{52}$ I am grateful to Carl Cranor for guidance on the difference principle. Ibid.

53 T.M. Scanlon, "Contractualism and Utilitarianism," in Utilitarianism and Beyond, Amartya Sen \& Bernard Williams, eds. (Cambridge University Press 1982), pp. 103-28.

54 T.M. Scanlon, What We Owe to Each Other (Harvard University Press 1998).
} 
potential to produce increased attention to fairness in the global economic order.

Scanlon states the basic working principle of contractualism as follows: "an act is wrong if its performance under the circumstances would be disallowed by any set of principles for the general regulation of behavior that no one could reasonably reject as the basis for informed, unforced general agreement."55 Scanlon prefers the negative formulation to the affirmative "that everyone could reasonably accept" because "unanimous acceptance is a consequence of this condition's being fulfilled, but is not itself the basic idea."56 Scanlon did not intend to formulate anything like a Pareto optimality requirement. Cohen has argued that an equivalent formulation for "no one could reasonably reject" would be "everyone must reasonably accept.,57 Arguably, these phrases are equivalent, but it is best to use the phrase adopted by Scanlon, since it is his theory.

In contractualism, the basis for moral wrongness or rightness lies in mutual recognition, a kind of mutuality. Mutual recognition lies in the motivational basis for contractualism. Scanlon's contractualism is not Hobbsian. People do not enter into agreement out of any reasons of self-interest. ${ }^{58}$ Scanlon explains:

What distinguishes my view from other accounts involving ideas of agreement is its conception of the motivational basis of this agreement. The parties whose agreement is in question are assumed not merely to be seeking some kind of advantage but also to be moved by the aim of finding principles that others, similarly motivated, could not reasonably reject. ${ }^{59}$

Contractualism reflects the "idea of a shared willingness to modify our private demands in order to find a basis of justification that others also have reason to accept."60 The philosophical lineage of Scanlon's contractualism goes back to Rousseau, not Hobbes. ${ }^{61}$

A key aspect of Scanlon's contractualism is its justification requirement. Justification is necessary to his theory in two ways: first as a normative basis for determining the content of morality - for determining right and wrong and second as a way of characterizing that content. The focus of characterization is in something like a constructivist procedure, in determining

\footnotetext{
${ }^{55}$ Scanlon, 153, see also 4 and 227 of the article.

${ }^{56}$ Scanlon, 390, n. 8.

${ }^{57}$ Brad W. Hooker, "Scanlon's Contractualism, the Spare Wheel Objection, and Aggregation," http//www.ucl.ac.uk/spp/download/seminars/Scanlons_Contractualism.rtf.

${ }^{58}$ For a contemporary Hobbsian account see David Gauthier, Morals by Agreement (reprint ed. Oxford University Press 1987).

${ }^{59}$ Scanlon, 5.

${ }^{60} \mathrm{Ibid}$.

${ }^{61}$ Ibid.
} 
rightness or wrongness based on justification to others. ${ }^{62}$ In this sense, Scanlonian contractualism does not need a veil of ignorance. The veil is unnecessary because contractualism internalizes the requirement of justifiability in the reasonable rejection standard. The concept of avoiding a bias of self-interest exists in the requirement of taking action that others could not reasonably reject. The motivational basis for the reasonable rejection requirement already requires that agents consider others. Scanlon does not need to impose a veil of ignorance requirement in order to get to the point where people will be other-regarding. ${ }^{63}$ The lack of connection to Hobbes seems clear.

Contractualism accounts for morality in a narrow sense. It does not concern morality in a broader sense, where it has to do with a range of issues of individual moral conduct that do no harm or violate any duties to others. ${ }^{64}$ For example, contractualism does no work towards helping us understand whether harming the environment in and of itself is morally wrong. Its scope is limited to a narrower range of morality, with duties we owe to others. Harm to the environment is a value to the extent it is, within a reasonable rejection framework, harm to others. Reasons for rejection are personal, but their force as reasons may depend on impersonal value, say, if people are of the view, that protection of the environment is worthwhile. ${ }^{65}$ Scanlon argues that contractualism nevertheless applies to a broader range of human action than justice does, because justice has to do with social institutions. ${ }^{66}$ His interpretation of justice as outside the realm of the practical reason of individual agents seems questionable, but I think he is simply trying to cabin contractualism as something that applies to individual or private circumstances.

Scanlon provides guidance on the form of a contractualist argument. Consider the situation in which an agent must determine whether it is wrong to do $\mathrm{X}$ in circumstances $\mathrm{C}$. First, "deciding whether an action is right or wrong requires a substantive judgment on our part about whether certain objections to possible moral principles would be reasonable.," ${ }^{, 67}$ From here, we must look at burdens and benefits. To determine what is reasonably rejectable by others, "we . . . need to form an idea of the burdens that would be imposed on some people in such a situation if others were permitted to do X." ${ }^{\circ 8}$ Scanlon calls these "objections to permission." "69 We must compare objections to permission

\footnotetext{
${ }^{62}$ Ibid., 189.

${ }^{63}$ Ibid., 207.

${ }^{64}$ Ibid., 6-7.

${ }^{65}$ Ibid., 220.

${ }^{66}$ Ibid.

${ }^{67}$ Ibid., 194.

${ }^{68}$ Ibid., 195.

${ }^{69}$ Ibid.
} 
to "objections to prohibition," which focus on benefits to others. ${ }^{70}$ We then can compare these two sorts of objections to derive a judgment about whether $\mathrm{X}$ is morally permissible. Scanlon explains:

If the objections to permission are strong enough, compared to the objections to prohibition, to make it reasonable to reject any principle permitting doing $\mathrm{X}$ in $\mathrm{C}$, then one would not expect the objections to prohibition to be strong enough, compared to the objections to permission, to make it reasonable to reject any principle that forbids doing $\mathrm{X}$ in $\mathrm{C}$. $^{71}$

In contractualism, objections derive from principles, not merely from effects or states of affairs. This does not mean that principles cannot take states of affairs into account. The degree of harm a principle causes is directly relevant to its fairness. Contractualism, however, does not focus solely on states of affairs; principles guide any consideration of states of affairs. The focus is on why an action is wrong. Reasons are thus paramount. This sort of thinking should not be exceptional to lawyers. For example, we would consider accidental harm different from intentional harm, even if the effects were the same. In determining whether to build a road or a school or an electrical transmitter, we accept the non-negligent injury or even death of a limited number of workers and possibly bystanders as socially acceptable risk. We can even determine with some degree of statistical confidence that such injuries or deaths will occur. On the other hand, the law does not accept intentional harm inflicted on a few people so that many will benefit. Scanlon offers the example of electrical equipment falling on the arm of a worker in a transmitter room of a television station broadcasting a World Cup match. We certainly would not sanction the failure to remove the worker from harm in order to continue the broadcast. We would want to rescue her before the match is over. $^{72}$

We can understand the nature of objections to permission and prohibition is in what Derek Parfit's characterization of Scanlonian contractualism as a "Complaint Model" of ethical decision-making. ${ }^{73}$ In such a model, only individuals can raise objections, which means that there can be no aggregation or summing of costs and benefits, because such aggregation or summing can result in the burdening of some groups to benefit others. Scanlon explains:

A contractualist theory, in which all objections to a principle must be raised by individuals, blocks such justifications in an intuitively appealing way. It allows the intuitively compelling complaints of those who are severely burdened to be heard,

\footnotetext{
${ }^{70} \mathrm{Ibid}$.

${ }^{71}$ Ibid.

${ }^{72}$ Ibid., 235-36.

${ }^{73}$ Ibid., 229.
} 
while, on the other side, the sum of the smaller benefits to others has no justificatory weight, since there is no individual who enjoys those benefits and would have to forgo them if the policy were disallowed. ${ }^{74}$

Utilitarianism permits aggregation, but contractualism does not, except in a very narrow range of circumstances involving "ties." A tie is a situation in which the moral seriousness of, say, two states of affairs is equivalent, but one situation involves harm to more people than the other does. In such a situation, it is permissible to choose the alternative that causes harm to the fewer number of persons. In situations not involving ties, which Scanlon seems to think are the overwhelming majority of situations, we must look to principles to choose the appropriate course of action. ${ }^{75}$

Scanlon gives us some hint on how we could apply his contractualist principle to questions about global justice. In a section of his book on whether there should be a priority for the worst off, Scanlon elaborates two principles, the Rescue Principle and the Principle of Helpfulness. ${ }^{76}$ Both have as their scope the question whether a duty to render aid exists. Aid rendering duties have been the subject of longstanding questions of Kantians, consequentialists and virtue ethicists. The basic point of discussion is, how other-regarding should I be? Do I have to depart from my own life projects to aid others? Can I consider my own interests?

Scanlon contends that in some cases the question of priority never arises. ${ }^{77}$ His example is the obligation to keep a promise, a subject he devotes a good bit of discussion to in his book. Therefore, as a preliminary matter, it seems contractualism will excuse from the discussion of distributive justice any preexisting obligations. Scanlon does not say much about this limitation. It has the potential to be a very significant limitation and is worthy of future exploration.

Scanlon says that a principle of priority for the worst off "has greater plausibility when we turn from principles whose aim is to create some specific form of protection or assurance to principles which tell us how we should distribute some transferable good, in cases in which the value of this good to potential beneficiaries is the dominant consideration., ${ }^{, 78}$ The cases in which it is most clearly wrong not to give aid are cases in which others are in serious difficulties, where their lives are immediately threatened, they are starving, in great pain, or "living in conditions of bare subsistence." 79 He articulates his

\footnotetext{
${ }^{74}$ Ibid.

${ }^{75}$ Ibid.

${ }^{76}$ Ibid.

${ }^{77}$ Ibid.

${ }^{78}$ Ibid., 224.

${ }^{79}$ Ibid.
} 
Rescue Principle for these cases: "if you are presented with a situation in which you can prevent something very bad from happening, or alleviate someone's dire plight, by making only a slight (or even moderate) sacrifice, then it would be wrong not to do so." ${ }^{, 80}$ Thus, it would be unreasonable for me to reject a moral duty to give a charitable contribution to the victims of the recent tsunami. The Principle of Helpfulness, on the other hand, applies when someone else not in dire need would benefit from my help, and my help would mean a slight to moderate sacrifice on my part.

Do these principles seem weak? They try to steer away from the problem faced by moral (but not legal) utilitarianism that it asks too much of agents. Scanlon allows us to consider our own life plans. Scanlon argues that it would be reasonable to reject a principle requiring us to give no more weight to our own interests than to the "similar interests" of others. ${ }^{81}$ He explains, "what is appealed to is not the weight of my interests or yours but rather the generic reasons that everyone in the position of the agent has for not wanting to be bound, in general, by such a strict requirement., ${ }^{, 82}$

Of course, we must be fair to Scanlon here. His discussion is limited to the question of whether individuals - not governments - have a duty to render aid. The public international analogue is aid and development assistance, though we should not jump to the analogy without providing proper reasons for the extension of contractualism from the private to the public sphere. We cannot suggest his principles as anything other than heuristics for evaluation of WTO (or other) policies and institutions without some account of how contractualism is a public form of morality, something of sufficiently broad scope that it is the subject for another paper. The most glaring omission in contractualism as it stands now is a theory of justice about public institutions. The bottom line for contractualism is that, in contrast to Rawls's theory of justice, a "priority of the worst off" is a "feature of certain particular moral contexts rather than a general structural feature of contractualist moral argument." ${ }^{83}$ Scanlon admits that such a priority is a central feature of Rawls's difference principle, but he is careful to explain that while Rawls starts from the idea that equal participants in a fair system of social cooperation have a prima facie claim to an equal share in the benefits it creates. In his constructivist account, Rawls tries to neutralize luck created in the natural lottery of birth, nationality and so on. Contractualism, lacking a political idea of equality, makes no claims about equality or initial endowments.

Do we want to extend contractualism into the public realm, to evaluate in our particular case the fairness of global economic treaties? Some scholars,

\footnotetext{
${ }^{80} \mathrm{Ibid}$.

${ }^{81}$ Ibid.

${ }^{82}$ Ibid., 225.

${ }^{83}$ Ibid., 228.
} 
such as Leif Wenar, contend that contractualism is adequate but that the main task of the contractualist is empirical and not philosophical. He argues that "if the causal links are good - that if, if rich individuals can in fact improve the long-term well-being of the poor and their descendants through direct action with their time and money - then contractualism may place on rich individuals quite significant demands." ${ }^{\circ 4}$ Wenar's argument is good as far as it goes for the construction of a moral principle in the realm of private morality, but I believe that we need to do more work to get an adequate account of contractualism to compare with Rawls's theory of justice. For now, we can use Scanlon's principles as heuristics.

\section{A Sketch of How to Apply Fairness Criteria: TRIPs and Access to Medicines}

In his article, "Global Economics and International Economic Law," Jackson explains that "[d]istributive justice suggests a variety of policies within the scope of a domestic market: progressive taxation, welfare, safety nets, a social market economy, etc. But, internationally, of course, we have this problem also: the low income countries argue for certain preferences. Garcia has done important work on the application of Rawlsian principles of fairness to special and differential treatment. ${ }^{86}$ The next steps are to evaluate the basic policies and normative structures in the WTO agreements and international economic institutions generally.

As for normative structures, a place to start is in understanding the fairness of the most basic of the traditional tools of the trade lawyer - national treatment and most favored nation $(\mathrm{MFN})$ obligations. When is national treatment or MFN reasonably rejectable by a WTO member? Quotas are also an obvious target of analysis. From these basic disciplines, we could move to examining non-tariff barriers to trade and areas of substantive regulation. TRIPs and the Sanitary and Phyto-Sanitary Agreement seem apt for some sort of contractualist analysis. Subsidies is another area in which a fairness analysis could tell us much. The recent Upland Cotton decision, in which the WTO Appellate Body, upheld a ruling by a dispute settlement panel that U.S. subsidies to cotton farmers in part violated the Subsidies and Countervailing Measures Agreement and distorted trade, suggests a subject for further inquiry

\footnotetext{
${ }^{84}$ Leif Wenar, "Contractualism and Global Economic Justice, in Global Economic Justice, Thomas W. Pogge, ed. (Blackwell 2001): 81-82.

85 John H. Jackson, The Jurisprudence of GATT and WTO: Insights on Treaty Law and Economic Relations (Cambridge University Press 2000): 451.

86 Frank J. Garcia, "Trade and Inequality: Economic Justice and the Developing World," Michigan Journal of International Law, 2000, 21: 975
} 
using Scanlonian or Rawlsian principles. ${ }^{87}$ We could assess the fairness the WTO dispute settlement process itself using these principles. We could gain insights by using the tools of moral philosophy to understand, for example, the effects of dispute settlement policies on low-income countries or on inadequately represented groups. In addition to the need for a philosophical account to transition Scanlon (and other) ethical theories to conceptions of political justice, the next steps are empirical: institutionally oriented studies of the details of the world trading system.

As an example, I examine the effect of TRIPs on access to medicines in low-income countries. The subject of access to medicines has received a good deal of attention. The attention focuses on the devastation that disease has brought to the low-income countries, particularly countries in sub-Saharan Africa. Intellectual property rights are but one feature of the global health delivery system, one that is isolable and relates directly to the work of the WTO.

The link between poverty, poor health and access to medicines is indisputable. According to a report written by economist Jeffrey Sachs for the World Health Organization, "[t]he linkages of health to poverty reduction and to long-term economic growth are powerful, much stronger than is generally understood. The burden of disease in some low-income regions, especially sub-Saharan Africa, stands as a stark barrier to economic growth . . ., 88 The main causes of avoidable deaths in the least developed countries are the result of HIV/AIDS, malaria, tuberculosis, childhood infectious diseases, maternal and perinatal conditions, deficiencies in nutrition and illness related to tobacco use. Many of these diseases are preventable or curable. Sachs estimates that if developed countries were to allocate only 0.1 percent of their GNP to assistance in health care, they could save 8 million lives per year in the lowincome countries. ${ }^{89}$ Sachs explains:

This program would yield economic benefits vastly greater than its costs. Eight million lives saved from infectious diseases and nutritional deficiencies would translate into a far larger number of years of life saved for those affected, as well as higher quality of life. Economists talk of disability-adjusted life years (DALYs) saved, which add together the increased years of life and the reduced years of living with disabilities. We estimate that approximately 330 million DALYs would be saved for each 8 million deaths prevented. Assuming, conservatively, that

87 United States - Subsidies on Upland Cotton, Report of the Appellate Body WT/DS267/AB/R, March 3, 2005.

${ }^{88}$ Macroeconomics and Health: Investing in Health for Economic Development: Report of the Commission on Macroeconomics and Health (Geneva: World Health Organization 2001):1.

${ }^{89}$ Ibid., 10-11. 
each DALY saved gives an economic benefit of 1 year's per capita income of a projected $\$ 563$ in 2015, the direct economic benefit of saving 330 million DALYs would be $\$ 186$ billion per year, and plausibly several times that. Economic growth would also accelerate, and thereby the saved DALYs would help to break the poverty trap that has blocked economic growth in high-mortality low income countries. This would add tens or hundreds of billions of dollars more per year through increased per capita incomes. ${ }^{90}$

Malaria, a preventable disease, all but eradicated in the North, continues to plague the South and correlates strongly to poverty and poor economic growth. ${ }^{91}$

Some consider access to medicines a human right. The UN High Commissioner for Human Rights and the World Health Organization accept this approach. ${ }^{92}$ Article 12 of the International Covenant on Economic, Social and Cultural Rights recognizes "[t]he right of everyone to the enjoyment of the highest attainable standard of physical and mental health." ${ }^{, 93}$ Rights arguments are fatally imprecise because they tell us nothing about obligations and requirements, and of course, intellectual property rights holders have rights that may conflict with the nebulous human right to health. Rights talk has gotten us little. These rights are either unenforceable or inapplicable. The international human rights covenants require countries that ratify them to conform their domestic laws to the covenants. Countries do not have to ratify these covenants. Indeed, the United States has not ratified the International Covenant on Economic, Social and Cultural Rights. Some countries, such as the United States, will not ratify a human rights covenant unless its laws already conform to the covenant, i.e., unless the covenant conforms to domestic law. Even if a country ratified the International Covenant on Economic, Social and Cultural Rights, it would impose no obligations on the country to improve access to health care in other countries. These weak human rights regimes contrast starkly to the strong intellectual property rights protection in TRIPs, mandatory if a country is a WTO member. TRIPs is a multilateral agreement; all WTO members must comply, though low-income countries had more time to achieve compliance as a result of transition periods contained in TRIPs. I show below how rights arguments go wrong and how an alternative formulation, one based on requirements and obligations, might

\footnotetext{
${ }^{90}$ Ibid., 12-13.

91 John Luke Gallup \& Jeffrey D. Sachs, “The Economic Burden of Malaria," Am. J. Trop. Med. Hyg. 64 (2001): 85-96.

92 Office of the High Commissioner for Human Rights, Human Rights and Trade, $5^{\text {h }}$ Ministerial Conference, Cancun, Mexico, 10-14 September 2003.

93 International Covenant on Economic, Cultural and Social Rights, Art. 12.
} 
work. Whether obligations on one person or set of persons gives rights to others, I leave for future discussion.

\section{A. TRIPS and the Doha Declaration}

Property rights have been a prime area of controversy for several centuries. It would be difficult to challenge the argument that no other category of legal rules affects the distribution of wealth more than property rules. Hume postulated as his central reason why people engage in society is for stability in the possession of property. ${ }^{94}$ His reason looks very much like what rational choice theorists characterize as a Nash equilibrium. The political economics of British agriculture in seventeenth and eighteenth centuries worked to produce the enclosure movement in Britain, the so-called first enclosure movement, in which the monarchy enclosed commons areas, such as copyholds of the yeomanry, to expropriate the rights of small farmers in estates. ${ }^{95}$

While the battle in the first enclosure movement was over rights in agricultural land, the battle in the second enclosure movement is in rights over products of the mind, which includes pharmaceuticals and biotechnology. The contested rights are in intangible property, intellectual property. ${ }^{96}$ Similes and metaphors abound in the literature. We are in the process of the second enclosure movement the "enclosure of the intangible commons of the mind" and the "intellectual land grab." 97 The battle for rights in intellectual property is "an information arms race with multiple sides battling for larger shares of the global knowledge pool." 98 The enclosure of the intellectual commons is occurring in various disciplines of science and technology, including in information technology and cyberspace, and in biotechnology relating to pharmaceuticals, medicine and human genetics.

TRIPs is one of the most important international agreements relevant to the allocation of intellectual property rights in pharmaceuticals. Although an international trade agreement and not a domestic intellectual property law, TRIPS is relevant to the question of ownership of rights in pharmaceuticals. It specifies standards for the intellectual property laws of the WTO members. It is unlike any other trade agreement preceding it, unlike anything produced in the WTO framework since the GATT's humble beginnings as an agreement to

\footnotetext{
${ }^{94}$ David Hume, A Treatise of Human Nature (1739): Book III.

95 Hannibal Travis, "Pirates of the Information Infrastructure: Blackstonian Copyright and the First Amendment, Berkelely Tech. L. J. (2000): 777.

96 James Boyle, "The Second Enclosure Movement and the Construction of the Public Domain," Law \& Contemp. Problems (2003): 33.

97 Ibid.

${ }^{98}$ Charlotte Hess \& Elinor Ostrom, "Ideas, Artifacts, and Facilities: Information as a CommonPool Resource, Law \& Contemp. Problems 111 (2003).
} 
regulate tariffs. TRIPs harmonizes intellectual property protection at a high level of protection for rights holders, and this is one of its controversial characteristics.

The WTO members negotiated TRIPs as part of the Uruguay Round and it was thus negotiated from 1986 to mid-1994. It is one of the most important developments in the WTO regime. TRIPs has been described as "the most ambitious international intellectual property convention ever attempted" and as "the most comprehensive multilateral agreement on intellectual property. ${ }^{99}$ It would not be an exaggeration to say that in the Uruguay Round, multilateral co-operation in the WTO regime on intellectual property matters transformed from a casual indifference to an intense preference for rigorous standards. TRIPs does much more than impose the traditional WTO obligations of MFN and national treatment. It is the first international trade agreement to specify minimum standards of protection and universal coverage of intellectual property rights. It imposes positive obligations on WTO members to protect seven categories of intellectual property. ${ }^{100}$ The standards in TRIPs reflect the high standards of intellectual property protection typically found in the intellectual property laws of high-income countries. In effect, TRIPS harmonizes intellectual property protection. Low-income countries must meet the same standards as developed countries, although under the transition provisions of the Agreement, they had more time in which to achieve compliance with the Agreement. Developed countries had until January 1, 1996 to achieve compliance, developing countries until January 1, 2000, and least developed countries have until January 1, 2006. ${ }^{101}$ In addition to high substantive standards that all WTO members must follow, TRIPs mandates untried procedural requirements for enforcing intellectual property rights. TRIPs directs WTO members on the details of how their enforcement system is supposed to enforce intellectual property rights within their borders. ${ }^{102}$ Moreover, disputes between WTO members over compliance with TRIPs are decided in the WTO dispute settlement system. ${ }^{103}$

Two TRIPs provisions are especially relevant to the affordable medicines debate: those dealing with patents and those dealing with compulsory licensing.

TRIPs requires that WTO members make patents lasting for at least twenty years from the date of the filing of the patent application available for "all inventions, whether products or processes." 104 The pharmaceutical industry

99 J.H. Reichman, "Compliance with the TRIPs Agreement: Introduction to a Scholarly Debate, Vand. J. Transnat'l L. (1996): 363.

${ }^{100} \mathrm{Ibid}$.

101 TRIPS Article 65.

102 TRIPS Articles 41-62.

103 TRIPS Article 64.

104 TRIPS Article 27. 
was particularly interested in having TRIPs require that all WTO members protect product patents. India, for example, has a long history of not recognizing product patents. India is a low-income country with many individuals paying health care expenses out-of-pocket. For many years India's substantial pharmaceuticals industry, in 2002 the largest producer of generic drugs in terms of volume, focused on the reverse engineering of pharmaceuticals and in the production of inexpensive drugs for a low-income population. ${ }^{105}$ Drug prices were in India thousands of percent lower than the patent protecting prices in higher income countries. To comply with TRIPs, India had to amend its patent hw to recognize product patents. In 2002, India amended its patent law to conform to TRIPs. The Patents (Amendment) Act of 2002, which went into effect in May 2003, recognizes twenty-year product patents on pharmaceuticals. 106

Compulsory licensing is a concept known principally outside of the United States. It is the license granted to produce a patented product over the objection of the patent holder. ${ }^{107}$ The license may run either to a government or to a user the government authorizes. TRIPs authorizes compulsory licensing but imposes a number of conditions. Before undertaking compulsory licensing, a government must try, "over a reasonable period of time," to negotiate "reasonable commercial terms" from the rights holder. ${ }^{108}$ A WTO member may waive these requirements in the event of a "national emergency." "109 Any use of the compulsory license must be "predominantly for the supply of the domestic market" of the WTO member. ${ }^{110}$ Finally, the right holder must be paid "adequate remuneration in the circumstances of each case, taking into account the economic value of the authorization.",111

The Marrakech Agreement Establishing the World Trade Organization requires that the WTO members hold ministerial conferences at least once every two years. ${ }^{112}$ A ministerial conference is the highest level of decision making in the WTO system. The WTO members held the Doha Ministerial Conference in late 2001. In that ministerial conference, the WTO members

105 Shubham Chaudhuri, Pinelopi K. Goldberg \& Panle Jia, "The Effects of Extending Intellectual Property Rights Protection to Developing Countries: A Case Study of the Indian Pharmaceutical Market," NBER Working Paper Series, Working Paper No. 10159, http://www nber.org/papers/w10159.

${ }^{106}$ Ibid.

107 Alan O. Sykes, TRIPs, Pharmaceuticals, Developing Countries, and the Doha 'Solution,'” University of Chicago John M. Olin Law and Economics Working Paper No. 140, http://www.law.chicago.edu/Lawecon/index html: 7.

${ }_{108}$ TRIPs Article 31.

${ }^{109}$ Ibid.

${ }^{110}$ TRIPs Article 31(f).

${ }^{111}$ TRIPs Article 1(h).

${ }^{112}$ Agreement Establishing the World Trade Organization Article 4. 
agreed on November 14, 2001 to the "Declaration on the TRIPs Agreement and Public Health." 113 The so-called "Doha Declaration" states that the WTO members "recognize the gravity of the public health problems afflicting many developing and least-developed countries, especially those resulting from HIV/AIDS, tuberculosis, malaria and other epidemics"114 and "stress the need" for TRIPs to be "part of the wider national and international action to address these problems." "15 On the other hand, the Declaration recognizes that "intellectual property protection is important for the development of new medicines," and "the concerns about its effects on prices." "16 The WTO members agreed that TRIPS "does not and should not prevent Members from taking measures to protect public health," and that TRIPS "can and should be interpreted and implemented in a manner supportive of WTO Members' right to protect public health and, in particular, to promote access to medicines for all."117 The Declaration contains the following steps that are more concrete:

(1) "Each Member has the right to grant compulsory licences and the freedom to determine the grounds upon which such licences are granted."118 This section informs that compulsory licensing is a matter of national discretion. $^{119}$

(2) "Each Member has the right to determine what constitutes a national emergency or other circumstances of extreme urgency, it being understood that public health crises, including those relating to HIV/AIDS, tuberculosis, malaria and other epidemics, can represent a national emergency or other circumstances of extreme urgency." 120 This section provides that the current health crises in the low-income countries are "national emergencies" and that negotiations with rights holders before issuing compulsory licenses is unnecessary.

(3) "The effect of the provisions in the TRIPs Agreement that are relevant to the exhaustion of intellectual property rights is to leave each Member free to establish its own regime for such exhaustion without challenge, subject to MFN and national treatment provisions. ..."121 This provision provides that

\footnotetext{
113 Hereinafter referred to as the "Doha Declaration."

114 Doha Declaration Art 1.

115 Ibid., Art 2.

116 Ibid. Art 3.

117 Ibid. Art. 4.

${ }^{118}$ Ibid. Art. 5(b).

119 Sykes, 9.

${ }^{120}$ Doha Declaration Art. 5(c).

${ }^{121}$ Ibid. 5(d).
} 
WTO members may permit parallel imports so long as they are not discriminatory. ${ }^{122}$

(4) The last section of the Declaration, among other things, "reaffirm[s] the commitment of developed-country Members to provide incentives to their enterprises and institutions to promote and encourage technology transfer to least-developed country Members pursuant to Article 66.2",123

The Declaration left open for future work by the TRIPs Council the problem of lack of pharmaceutical manufacturing capability in some low income countries. ${ }^{124}$ Compulsory licensing would not be helpful towards alleviating public health crises in a country lacking the capability to produce drugs. The TRIPs Council was required to report to the General Council by May 2002. The outcome of this additional work is a Decision of the General Council of 30 August 2003, in which least developed countries and countries that notify the WTO of their lack of capability may import pharmaceutical products from eligible countries. The conditions for such exporting and importing are strict. I will not go into the details of the Decision here because they do not affect the analysis to follow.

\section{B. Refocusing Towards Principles and Obligations}

From an economic standpoint, it is widely held that strong global intellectual property rights have questionable welfare effects. From an economic standpoint, TRIPs might be welfare reducing and rent shifting, with the rents shifting from the poor to the rich. It is not at all clear that intellectual property rights are necessary for innovation. ${ }^{125}$ I will not spend time explaining these economic points, as others have spent a good deal of effort on them. Add to these findings of normative welfare economists the findings of political economists, who argue that TRIPs is the product of industry capture, ${ }^{126}$ and we certainly have a questionable state of affairs even from an efficiency point of view.

122 Sykes, 8.

${ }^{123}$ Doha Declaration Art. 7.

124 Ibid. Art. 6

${ }^{125}$ For examples of the burgeoning literature, see Chaudhuri, Goldberg \& Jia; Michael Boldrin \& David K. Levine, "The Case Against Intellectual Property," American Economic Review Papers and Proceedings 92 (2002): 209-12; Michael Boldrin \& Daniel K. Levine, "The Economics of Ideas and Intellectual Property," Proceedings of the National Academy of Sciences, forthcoming, 2004.

126 The literature is substantial, but for a recent work on public choice and the proliferation of intellectual property rights generally, see William M. Landes \& Richard A. Posner, "The 
Part of the problem is a poverty of discourse, stemming from the focus on property rights. The contentious compulsory licensing permissions coming from Doha are an example of how property rights arguments skew the debate. We have to talk about derogations from those rights and go through all sorts of efforts to get derogations. And, what if the pro-property rights lobby is right as to particular life-saving drugs? What if the derogations, or some of them, harm innovation in particular cases?

An intellectual property rights regime by itself is an incomplete solution. Focusing also on obligations or requirements will allow for the stimulation of innovation while simultaneously providing for access to medicines in lowincome countries.

\section{The Rawlsian Approach}

Though this paper introduces a Scanlonian approach to examining the question of fairness of trade agreements, we should also take a brief look at how a Rawlsian approach might fare. Let us apply Rawls's second principle to the problems associated with intellectual property rights and affordable medicines. This second principle itself contains two principles, the fair equality of opportunity principle and the difference principle. We will not be able to come up with definitive answers because we need more empirical work, but we can put forth a framework for carrying on the analysis and reach tentative conclusions.

Here is how the analysis would proceed in determining whether TRIPs contravenes the fair equality of opportunity principle. In the context of the substantial need for affordable medicines in the low-income countries, the first question is whether TRIPS results in or contributes to over-protection of intellectual property rights. It results in overprotection to the extent that the rights that it creates and protects impair what Daniels calls normal species functioning. According to Daniels, "impairments to normal species functioning reduce the range of opportunity we have within which to construct life-plans and conceptions of the good we have a reasonable expectation of finding satisfying or happiness-producing. $" 127$ Daniels defines health care broadly. He divides heath care needs into five categories: (1) adequate nutrition and shelter, (2) sanitary, safe and unpolluted living and working conditions; (3) "exercise, rest, and other features of healthy life-styles;" (4) "preventive, curative, and rehabilitative personal medical services;" and (5)

Political Economic of Intellectual Property Law," AEI-Brookings Joint Center for Regulatory Studies (2004), http://www.aei.org/docLib/20040608 Landes.pdf.

${ }^{127}$ Daniels, 154. 
"non-medical personal and social support services"128 If over-protection of property rights in TRIPs impair these goods or their functional equivalents, then they violate the fair equality of opportunity principle.

The focus on affordable medicines in low-income countries is on Daniels' fourth category, the availability of medical services, including access to medicines to combat HIV AIDS, malaria, tuberculosis and other diseases common in low-income countries. To the extent that TRIPs impairs the ability of persons in low-income countries to obtain medicines of this sort, it violates the fair equality of opportunity principle. To meet the fair equality of opportunity principle, it is not required that these medicines be "free" or without cost to users. Rather, they should not be so costly as to unreasonably impair the life plans of individuals in the countries in question. In short, they should be affordable, with affordability determined based on some sort or means testing.

Though more research directly on these questions is necessary, the tentative evidence suggests that the fair equality of opportunity principle is not met in many situations in the low-income countries. Prices that are "patent protecting" make many drugs out of reach in the low-income countries. Risking an oversimplified picture of an otherwise rich contracting and firm structure, consumers (which may be countries where a public health system is the primary buyer of drugs) typically buy drugs from three kinds of sellers. First, they buy from the drug manufacturers themselves. This first avenue requires importing either from the firms who hold the patents for the drugs or from firms licensed by the patent holder to produce the drugs. Second, they import from a generic manufacturer, who might make the drug without any license from the patent holder, a possible solution only prior to when TRIPs came into full force. Third, they could buy the drugs from producers inside their own borders, who do not necessarily hold any license from the patent holder. India, for example, prior to bringing its patent system into compliance with TRIPs, could produce drugs cheaply and generically because it did not recognize product patents. TRIPs essentially collapses all these transaction forms into one: purchases from patent holders or their authorized producers. Doha provides some limited exceptions for compulsory licensing but it is too early to assess its effect.

The UN Millennium Project Task Force on HIV/AIDS, Malaria, TB, and Access to Essential Medicines describes as a barrier to the development of affordable new medicines the following:

[TRIPs] may block access to affordable new medicines and vaccines. After January 2005, generic production in India, the source of many vital existing medicines for developing countries without productive capabilities, will be fully subject to

${ }^{128}$ Ibid., 158. 
TRIPS provisions .... Concerns also exist that the August 30, 2003, decision reached by the WTO General Council concerning a waiver for TRIPS Article 31(f) (which would allow a compulsory license to be issued by the country in need and by the country that can produce the medicine for export) will be too cumbersome for developing countries to exploit .... Finally, the growing number of bilateral and regional trade agreements with major trading partners, such as the United States and the European Union, may often contain provisions that limit developing countries' use of existing flexibilities under TRIPS to protect public health (such as restrictive compulsory licensing conditions and parallel importation provisions, extended data protection, and forcing medicines regulatory agencies to take on national patent office oversight duties). ${ }^{129}$

This paper provides only a sketch of how to apply the Rawlsian criteria and therefore it does not provide any sort of statistical correlation between normal species functioning and drug prices, though the connection seems clear enough for some tentative conclusions. The logic is as follows: Illness is a major reason why people in low-income countries are poor. People in low-income countries are ill in large part because they cannot afford drugs to prevent or cure disease. Finally, they cannot afford drugs because of high patent protecting prices. The WHO has found:

The consequences of this inadequacy include an enormous loss of life from preventable or treatable diseases (such as tuberculosis, pneumonia, acute respiratory infections, malaria, diabetes, and hypertension) and significant human suffering, particularly among the poor and marginalized populations of the world. The lack of access to life-saving and health-supporting medicines for more than 2 billion poor people stands as a direct contradiction to the fundamental principle of health as a human right. Illness is a major reason that the nearly poor slide into profound poverty. Illness decreases people's ability to work (be it remunerative or not). Illness orphans children and prevents them from getting the education they need. Women and children make up the majority of the poor, and their low status in many societies often means that they have even less access to medicines. Improving access to medicines must be a key

${ }^{129}$ Beryl Leach, Joan E. Paluzzi \& Paula Munderi, Prescription for Healthy Development: Increasing Access to Medicines: UN Millennium Project Task Force on HIV/AIDs, Malaria, $T B \&$ Access to Essential Medicines (World Health Organization 2005): 24. 
component of strategies to strengthen healthcare. ${ }^{130}$

The WHO estimates that one-third of the world's population, about 1.7 billion people, lack access to the most basic essential medicines. ${ }^{131}$ In the poorest countries this figure increases to one-half. ${ }^{132}$ The WHO and the United Kingdom Department of Finance and International Development (DFID) have estimated that proper access to medicines would save about 4 million lives annually. ${ }^{133}$ From the standpoint of burdens on worst off groups, the poorest of the poor, pay the highest out-of-pocket expenses for medicines. ${ }^{134}$ Public sectors in developing countries cannot provide affordable medicines reliably. ${ }^{135}$ Medical insurance schemes cover only eight percent of the population in Africa and these schemes may not cover prescription medicines. ${ }^{136}$ The DFID has found a "mismatch between pharmaceutical needs in developing countries and the current nature of the global

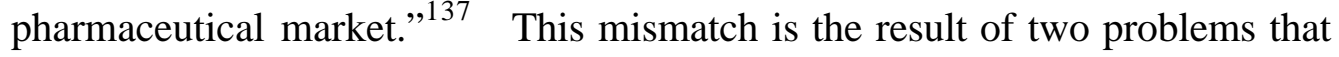
relate directly to intellectual property: the inability of people in low-income countries to pay for medicines and the resulting lack of incentives for pharmaceutical firms to develop medicines for diseases that disproportionately afflict persons in the low-income countries. ${ }^{138}$

The current regime of global intellectual property rights also seems to violate the Rawlsian difference principle. The difference principle essentially provides that inequality must benefit everyone. As long as the primary social goods of the worst off group are increasing, inequality is fair and can continue to increase. As soon as the primary social goods of the worst off group stop increasing, then the society in question has reached the maximum inequality permitted. We can conceptualize low-income countries or people in those countries as the worst off groups in global society. TRIPs makes people in low-income countries worse off. The current global intellectual property system, with patent protecting prices, makes the worst off groups, the poorest of the poor in low income countries, even worse off, while benefiting better off groups such as pharmaceutical firms in high-income countries. Much of the empirics that would support the analysis under the fair equality of opportunity principle would be relevant in the application of the difference principle as well. The main difference in the analysis, however, would be that Rawls's analysis of the difference principle facilitates some mathemetization in the

\footnotetext{
${ }^{130}$ Ibid., 42.

${ }^{131}$ Ibid., 43.

${ }^{132}$ Ibid., 43-44.

133 Ibid.

${ }^{134}$ Ibid.

135 Ibid.

${ }^{136}$ Ibid.

${ }^{137}$ Ibid.

${ }^{138}$ Ibid.
} 
form of comparisons of welfare based on the allocation of primary social goods.

The solutions to unfairness in the TRIPs regime would not differ from those suggested in the next section below. Notably, the Rawlsian fairness criteria do not specify a particular solution, but we can use them to understand the fairness of a solution. This is not a controversial point. In this sense, ethical standards do not differ from economic standards. They explain why but not how. The "how" is up to policy makers and lawyers.

As I have stressed in this paper, I have not provided a sufficiently detailed set of testable criteria for assessing TRIPs and fair equality of opportunity, though I have tried to provide a sketch of the issues that need further study. The purpose of this paper is to begin the exploration of methods for assessing fairness, not in providing definitive answers in the application to a particular area.

\section{The Scanlonian Approach}

The Scanlonian contractualist analysis proceeds in sketch form as follows. First, to use a phrase offered by Wenar, what do we owe to "distant" others? The answer in Scanlon's account would be principles no one could reasonably reject. Using Scanlon's terms, we would examine objections to granting intellectual property rights in pharmaceuticals versus objections to not granting them. ${ }^{139}$ The question may not be so binary, and it may be a question of the strength of those rights. Putting this into terms more easily understandable to lawyers, we would examine objections to patent rights versus objections to exceptions or derogations from patent rights. This gets us into examining burdens and benefits. As tentatively sketched out above, the burdens of poor health in low-income countries are substantial. On the other hand, losses to pharmaceutical companies do not necessarily follow. ${ }^{140}$ The benefits are improved health in the populations of to the low-income countries are substantial. It would seem that strong intellectual property rights are reasonably rejectable while weak (or in some cases no) rights are not. Can we develop these arguments through the articulation of a principle?

Scanlon's Principle of Rescue may be relevant. He articulates his Rescue Principle for these cases: "if you are presented with a situation in which you can prevent something very bad from happening, or alleviate someone's dire plight, by making only a slight (or even moderate) sacrifice, then it would be

\footnotetext{
139 The intellectual property right we will usually be concerned with for pharmaceuticals are almost always patents, so some places in the text will refer only to patent rights.

${ }^{140}$ Chaudhuri, Goldberg \& Jia.
} 
wrong not to do so." ${ }^{141}$ The Principle of Helpfulness, on the other hand, applies when someone else would benefit from your help, and your help would mean a slight to moderate sacrifice on your part. It would seem that the Principle of Rescue is more relevant, given the dire need for affordable medicines in the low-income countries.

I have sketched out above the burdens that TRIPs places on consumers of drugs in low-income countries. Recent economic research on antibiotics in the Indian pharmaceutical market indicates that these losses may be substantial, but that profit gains to pharmaceutical firms are orders of magnitude lower. ${ }^{142}$ Thus, it would seem that compulsory licensing or some other form of derogation from patent rights in pharmaceuticals could in certain cases result in substantial benefits to persons in low-income countries with only slight or moderate sacrifice to patent holders. The Principle of Rescue would seem squarely to apply in such circumstances.

Could we derive a Principle of Equality in Normal Species Functioning from contractualism? Recall that for contractualism a "priority of the worst off" is a "feature of certain particular moral contexts rather than a general structural feature of contractualist moral argument."143 Contractualism, lacking a political idea of equality, makes no claims about equality or initial endowments. Therefore, we might have difficulties with strict notions of equality because they might be reasonably rejectable by some. On the other hand, some limited notions of equality will survive the Scanlonian complaint model. A limited form of equality exists in the concept of health care as a means to obtain normal species functioning at the level outlined here. The argument is that health care (which includes availability of essential medicines) "has as its goal normal functioning and so concentrates on a specific class of obvious disadvantages and tries to eliminate them."144 The focus is not on eliminating all natural and social differences, but on eliminating natural and social disadvantages brought about by disease.

What if derogating from intellectual property rights in pharmaceuticals actually would do substantial harm to the incentive to innovate, to the point where worst off groups, and other groups, are made worse off? Some avenues nevertheless exist that would allow countries to meet the requirements of fair access to essential medicines while still preserving the rights of patent holders. The most obvious solution is donor assistance to low-income countries for the purchase of pharmaceuticals. Low-income countries tend not to have the manufacturing base to take advantage of compulsory licensing. The donor assistance approach would also avoid difficulties associated with parallel

\footnotetext{
${ }^{141}$ Ibid.

142 Chaudhuri, Goldberg \& Jia.

${ }^{143}$ Ibid., 228.

${ }^{144}$ Daniels, 166.
} 
importation of generic drugs. Donors would pay patent protecting prices. Such an approach shifts the question away from discussions of rights to health care to requirements on those able to provide assistance to provide it. In the current international legal system, no such obligations exist. Assistance is aid and aid is charity. Scanlon provides a procedure for deriving principles that no one can reasonably reject and that helps us identify obligations and requirements. Some countries have taken steps toward creating such obligations, though these obligations remain essentially self-imposed. The United Kingdom, for example, has undertaken a purchase commitment of 200300 million doses each of HIV/AIDS and malaria vaccines if such vaccines are developed. ${ }^{145}$ One purpose for a purchase commitment is to provide pharmaceutical firms with an incentive to innovate in the area of neglected diseases, which are found in low-income countries, where affordability at patent protecting prices is a major obstacle. ${ }^{146}$ Another possible form of obligation are trust funds, if countries could be obligated to submit funds to them. ${ }^{147}$

\section{Conclusion}

Developing and applying principles of fairness to global economic institutions is hard work. It would be easier simply to accept the dictates of power relations within the global economic system as a given and go from there. The limited goal of this paper is to produce more reflection on alternatives to economic efficiency and other quasi-utilitarian conceptions of normativity in the international economic order, with special reference to recent work in contractualist moral philosophy. I have tried to develop a few modest insights from moral philosophy into heuristics for evaluating trade agreements. I have tried to offer an account that differs from the Sen/Nussbaum capabilities approach. The broader notion here is that my approach is an alternative to the Sen/Nussbaum approach.

We are not far along on this process, and have much to do. Until we derive and use principles rather than almost totally rely on states of affairs, we will continue to neglect the question of justice in the world trading system.

${ }^{145}$ UK Chancellor Gordon Brown Announces Vaccine Purchase Commitments for HIV/AIDS and Malaria, http://www.cid.harvard.edu/books/kremer04_strongmedicine.html.

146 Micheal Kremer \& Rachel Glennerster, Strong Medicine: Creating Incentives for Pharmaceutical Research on Neglected Diseases (Princeton University Press 2004).

147 See, e.g., Sean D. Murphy, "Contemporary Practice of the United States Relating to International Law: International Economic Law: Debt Relief for Heavily Indebted Poor States," Am. J. Int'l L. 94 (2000): 133. 